\title{
Opinions of the final Year Secondary Health Care Students and the final Year Students of the Undergraduate Nursing Study Programme About Organ
} Donation

1 Želimir Đurić

2 Štefica Mikšić

${ }^{3}$ Biljana Kurtović

1 Department of Anesthesiology, Reanimatology and Intensive Care, „Dr. Ivo Pedišić” General Hospital, Sisak, Croatia

2 Faculty of Dental Medicine and Health, Osijek, Croatia

${ }^{3}$ University of Applied Health Sciences, Zagreb, Croatia

Article received: 20.02 .2019 .

Article accepted: 15.05.2019.

DOI: $10.24141 / 2 / 3 / 1 / 5$

Author for correspondence:

Želimir Đurić

Department of Anesthesiology, Reanimatology and

Intensive Care, „Dr. Ivo Pedišić“ General Hospital

Josipa Jurja Strossmayera 59, Sisak, Croatia

E-mail: zelimir.djuric@yahoo.com

Keywords: organ donation, organ transplantation, secondary school students, college students

\section{Abstract}

Aim. To examine and compare the opinions of the final year secondary health care students and the final year students of the undergraduate Nursing study programme about the significance of organ donation.

Methods. A cross-sectional study was conducted on a sample of 60 participants of whom 30 were undergraduate Nursing study programme students and 30 were secondary health care students. The research instrument was a questionnaire designed for the purpose of this study, which included the following groups of questions: the first group consisted of questions about the participants' general data, while the second group contained questions about organ donation itself.

Results. From the obtained results, it was determined that there is no statistically significant difference in the decision to donate organs depending on the level of education. Furthermore, the results show that both groups of participants want to donate organs and the main motivation is to rescue someone's life. In addition, the majority of participants express the view that such behavior is a humane act.

Conclusion. Education level does not affect organ donation decision-making. The main motivation for deciding on donating organs is to rescue someone's life. Organ donation is an act of humanity. In the survey, several respondents expressed negative opinion about organ donation. Therefore, it is recommended that workshops aimed at future health professionals, be organized in secondary health care schools and other educational institutions for healthcare professionals to emphasize the importance of organ donation. 


\section{Introduction}

According to the Medical Lexicon, transplantation is defined as "transplanting tissues or organs from one individual to another" (1). Organ transplantation refers to the transfer of an entire organ or parts of organs, cells or tissues from one person to another $(1,2)$.

Considering the organ donors, an organ can be transplanted from a living (ex vivo) or a deceased donor (ex cadavere) (2). Referring to the organ donor and recipient, we differentiate between autologous (from one place on the same body to another, e.g. skin), homologous (between the same species, from one person to another) and heterologous (between different species, from an animal to a human) organ transplantation $(3,4)$. Also, there has been an increase in the use of artificial organs, the so-called implants or engineered organs (2).

Body parts for the transplantation can only be retrieved from a deceased person after they have been declared to be dead by established medical criteria and methods of determining death (5). Organ transplantation process from a deceased person can only begin after the donor has been declared brain dead. Brain death signifies permanent loss of all brain functions of the cerebrum, cerebellum and the brainstem. When brain death occurs, no therapeutic interventions can restore it to its original functional state. Tests performed by a multidisciplinary team of specialists and nurses are used to prove brain death. These tests need to be repeated at least twice, and the end of the brain death diagnosis marks the time of death $(2,4)$.

The success of the organ transplantation procedure depends on the appropriate care for the donor after brain death diagnosis, which implies maintaining vital functions and preserving organs. The role of the nurse is essential in care for the organ recipient and the donor, during the explantation and transplantation process, and is manifested in interventions such as vital functions monitoring, airway passage maintenance and care to maintain proper artificial ventilation parameters, maintenance of cardiovascular system function, maintenance of fluids balance and normal body temperature, prevention of infection and the preservation of normal endocrine functions and spinal reflexes (6). In addition to providing care for the organ recipient, the nurse also provides care for the organ donor who is dependent on the level of knowledge and experience of the health care staff as well as the quality of the care provided.

Nurses are fully involved in the transplantation process from its beginning to the end, i.e. from preoperative patient preparation, assisting the surgeon during the transplantation process, to postoperative patient care. Once the procedure is completed, the nurse continues to monitor the patient's vital signs, administers pain relief drugs, monitors heartbeat and possible signs of organ rejection by the patient's body (7).

Organ donation is considered to be a social need that enables organ transplantation as a method of treatment. It signifies nobility and humanity reflected in a person's desire and intent to donate any part of one's body after death to help the severely ill. "A donor is a person who chose to donate one or several organs, be it while he/she is still alive or after death" (5). According to the Act on Human Organ Transplantation for Treatment Purposes (NN 144/12), body parts may only be used for transplantation if the deceased person had not written a statement against organ donation (5), or if his or her wish against donation had not been expressed to a family member. An organ or tissue from a living person can only be retrieved for the treatment of another patient when there is no matching organ or tissue from a deceased person or an equivalent treatment method (4). Human organs that can potentially be transplanted are kidney, pancreas, liver, lungs, heart or small intestine. Kidney transplantation enables a patient to discontinue dialysis, while pancreatic transplantation eliminates patient's need for insulin (8). Liver, lung, heart, and small intestine are transplanted to patients with endstage organ failure which endangers the patient's life. Tissue transplantation refers to the transplantation of skin, heart valve or blood vessel, cornea, bone and bone marrow (8).

The history of transplantation in Croatia began in 1971 when the first kidney transplantation was performed in Rijeka. Today, Croatia is known as one of the countries with the largest number of organ donors and transplants per million inhabitants (3). In 2007, Croatia has become a full member of the international organ exchange organization, Eurotransplant. Since then, the transplantation programme in the Republic of Croatia has been harmonized with the standards of the European Union and integrated into the European transplantation network. The 
Croatian Parliament adopted the act on retrieval and transplantation of human body parts for treatment purposes on December 3, 2004 (5). This act has established conditions for retrieval and transplantation of human body parts (organs and tissues) from a living or a deceased person for transplantation, for treatment purposes. The provisions of this act do not apply to reproduction organs and tissues, organs and tissues of an embryo or foetus, or blood and blood products.

The Croatian Donor Network (hereinafter referred to as HDM) began with its activities in Pula in 1998. The organization was created to inform the public about transplantations, post mortem donations and the need for organ retrieval for the purpose of successful treatment of seriously ill and terminal patients $(4,9)$. Initially, the Croatian donor network promoted post mortem organ donation, but it has expanded its activities to date. The Council of the Croatian Donor Network was established in 2001 with the aim to become more persuasive and have more strength in its public activities. The HDM organization today has around one hundred collaborating associations, both in Croatia and across the world. Workshops and lectures in universities, secondary and primary schools, and similar institutions are held to promote their principles. The activities of HDM have been part of the Transplantation Programme of the Croatian Ministry of Health since $2011(4,10)$.

\section{Aim}

The aim of this study was to examine and compare the opinions of the final year secondary health care students and the final year students of the undergraduate Nursing study programme about the importance of organ donation.

\section{Hypothesis}

There is no statistically significant difference in the participants' opinions about organ donation between the final year secondary health care students and the final year students of the undergraduate Nursing study programme.

\section{Methods}

The research was conducted in 2018, and the participants were 60 participants, 30 final year secondary health care students from Sisak and 30 final year students of the undergraduate Nursing study programme in Bjelovar.

The research instrument was a 13 -item questionnaire designed for the purposes of the present study. The questionnaire consists of two parts, the first was used to elicit the participants' general data, while the second part contains questions about organ donation. Some items are dichotomous (yes or no), some have a third option (I do not know), while some are multiple choice items for which the participants could choose several of the provided answers.

\section{Data Processing Methods}

Participants' responses were entered into MS Excel. The data are presented in tables as absolute and relative frequencies. Furthermore, the correlation between the response and the degree of education was analysed and tested by the $\chi^{2}$ test and the Fisher's test. Wilcoxon's test was used to test the equality of data distribution between secondary school and college students for the multiple choice questions with multiple responses. All these tests were made using the statistical programming language $R$, and for each test the level of significance was 0.05 . 


\section{Results}

The research was conducted among third year students of the undergraduate Nursing study programme at the Polytechnic in Bjelovar ( $\mathrm{N}=30)$ and among health care students at the Viktorovac secondary school in Sisak $(\mathrm{N}=30)$. Two secondary school students' questionnaires were excluded from the analysis because they were incomplete. Questionnaires were correctly completed by 58 participants, of whom 44 were female and 14 were male. Figure 1 shows the ratio of female and male participants, and the binomial test confirmed significant differences in gender distribution $(p<0.001)$.

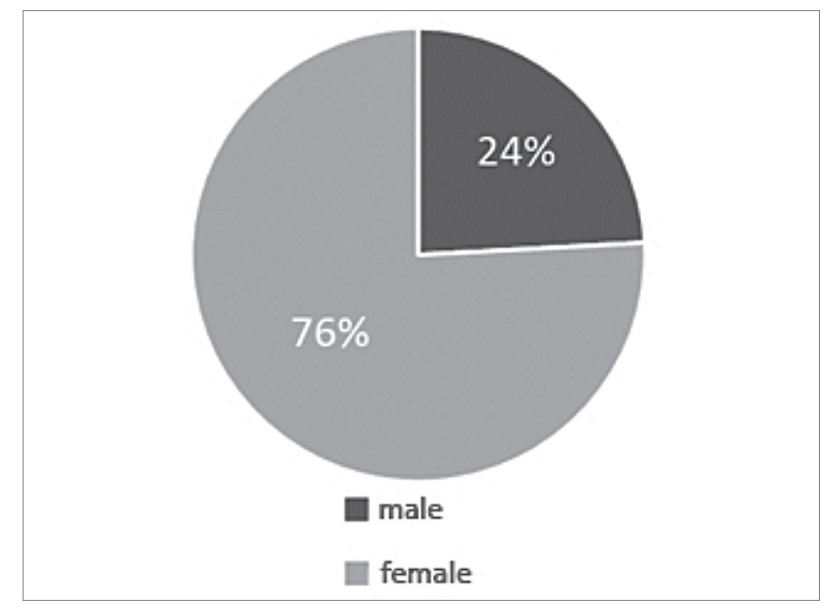

Figure 1. Gender distribution of the participants

The data on participants' age are divided into three categories (18-25 years, 26-35 years, 36 and more), and the percentage of students in the 18-25 age group is the highest.

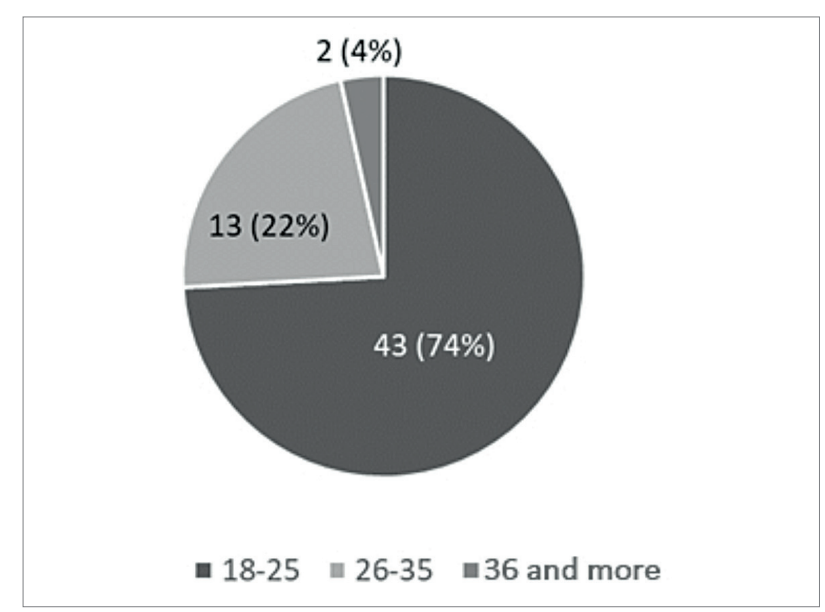

Figure 2. Age distribution of the participants
The distribution of the participants according to their religious beliefs, presented in Figure 3 , shows that 51 participants (88\%) declared themselves as believers (yes) and 7 (12\%) as unbelievers (no).

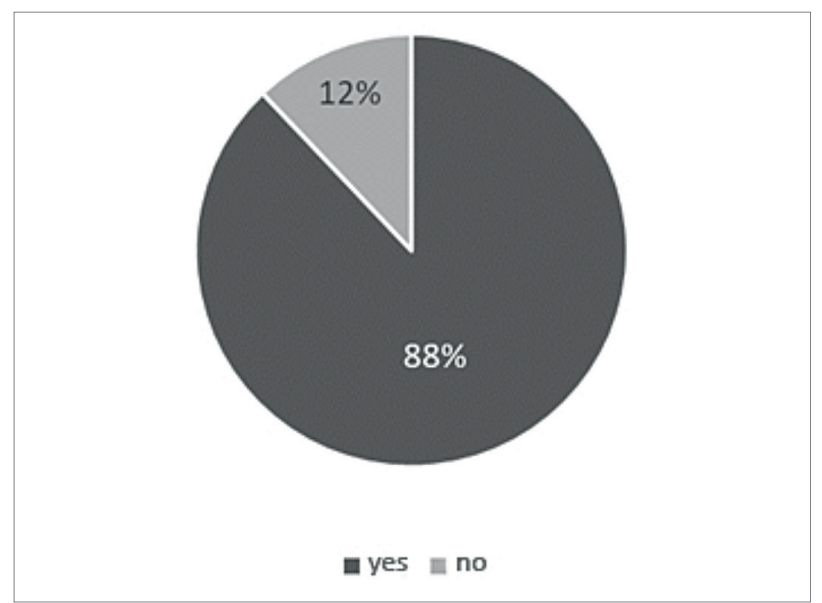

Figure 3. The participants' distribution according to their religious beliefs

The descriptive analysis of the participants is followed by a comparison of the secondary school and college students' opinions and attitudes, which is the main objective of the statistical data processing. Table 1 shows the structure of the participants' responses pertaining to their willingness to donate organs, while Graph 1 presents age distribution of the participants' responses.

\begin{tabular}{|c|c|c|c|}
\hline & $\begin{array}{l}\text { Secondary } \\
\text { school } \\
\text { students }\end{array}$ & $\begin{array}{l}\text { College } \\
\text { students }\end{array}$ & Total \\
\hline yes & 21 & 21 & 42 \\
\hline no & 3 & 1 & 4 \\
\hline $\begin{array}{l}\text { I do not } \\
\text { know }\end{array}$ & 4 & 8 & 12 \\
\hline Total & 28 & 30 & 58 \\
\hline
\end{tabular}

The objective of applying statistical tests was to examine whether there was a difference in willingness to donate organs between secondary and college students, and, based on the results of the Fisher's exact test $(p=0.356)$, it may be concluded that there is no difference according to the participants' education level. 
The second item in the questionnaire was multiple choice item. There was a total of 123 responses and the most common reason for the participants' choice to donate their organs in both groups was the opportunity to save someone's life.

The results presented in the graph indicate that both groups have very similar attitudes. Using the Wilcoxon test, no statistically significant difference was found between the responses of the secondary and college students $(W=1919.5, p=0.731)$.

The third item in the questionnaire inquired into the reasons why the participants would not want to be organ donors. A total of 60 responses were obtained, with almost $50 \%$ of the participants expressing the wish to be donors. The structure of the responses given by the secondary school and college students is shown below, and the Wilcoxon test confirmed that there is no sta- tistically significant difference according to the participants' level of education ( $W=361.5, p=0.499)$.

The next item in the questionnaire is related to the secondary school and college students' willingness to donate the organs of their immediate family members after their death.

The Fisher's exact test showed no statistical difference in the attitudes between the two groups $(p=0.207)$. Moreover, based on the results presented in Graph 4, it can be concluded that the differences are minimal.

Most participants reported that a person's identification card should state whether one is a donor or not. Table 2 shows that there are some differences in the participants' attitudes, but the Fisher's test confirms they are not significant $(p=0.623)$.

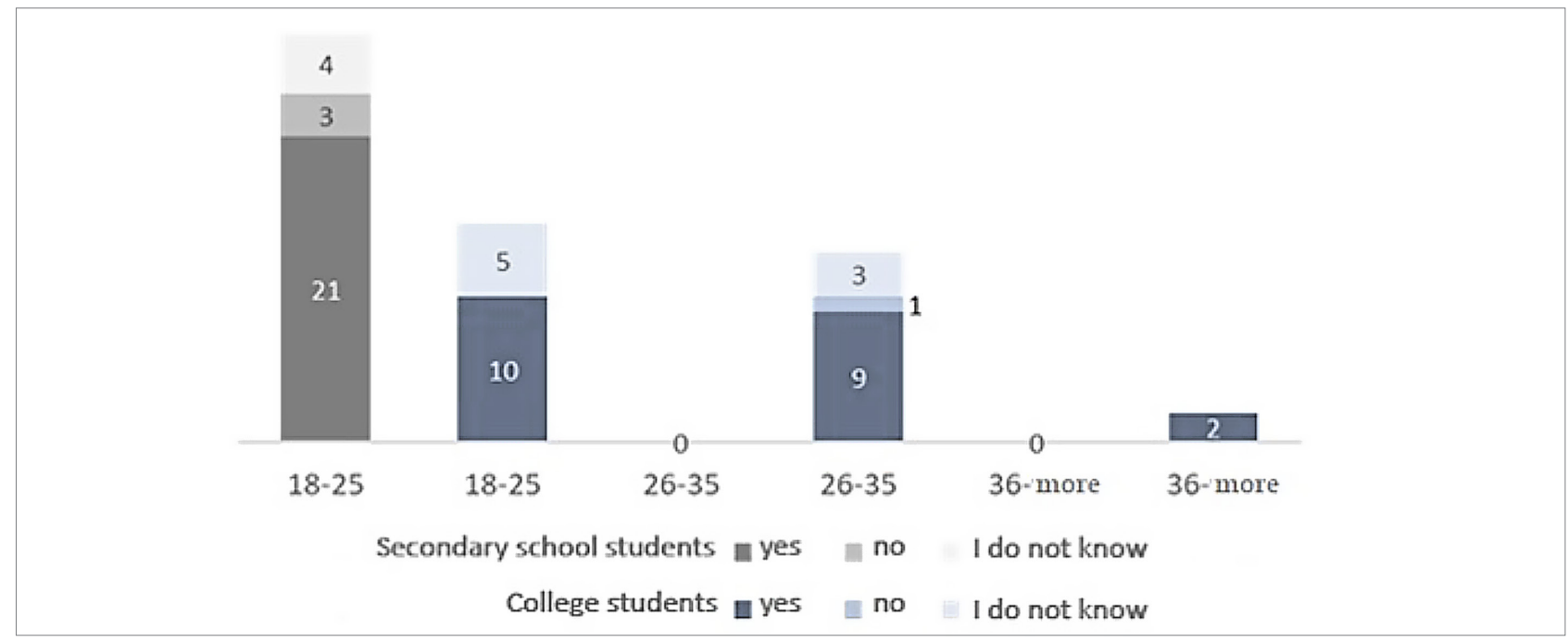

Graph 1. The participants" willingness to donate organs according to their age and level of education

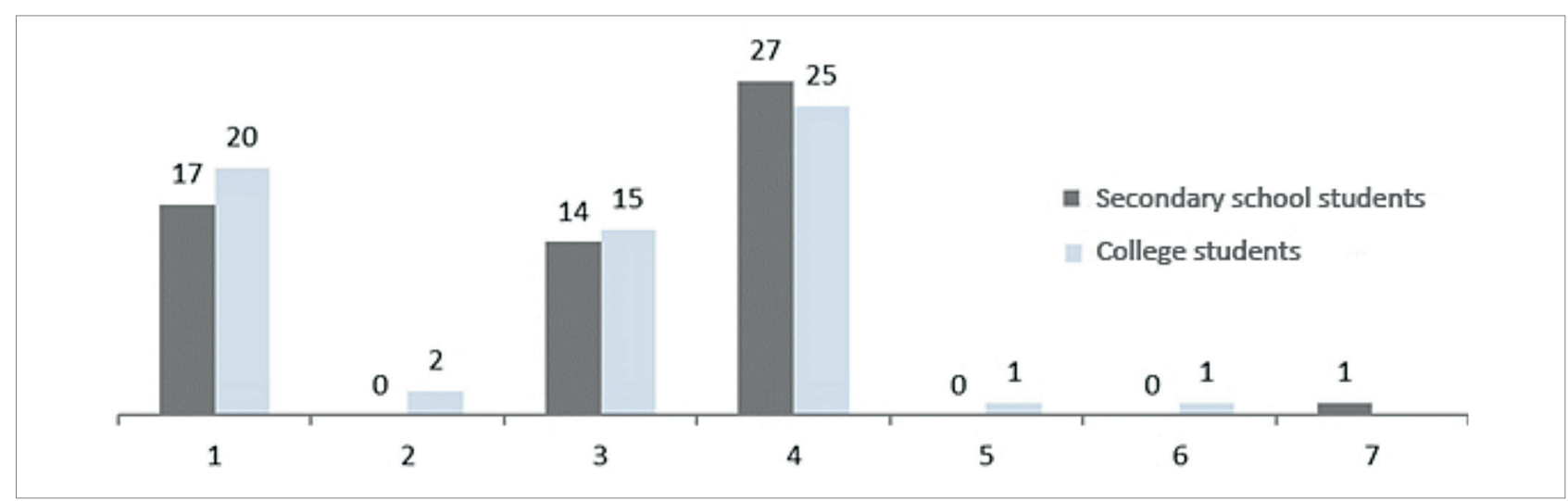

Graph 2. Frequencies for the responses to the item "Choose the reasons why you would personally want to be an organ donor" 
Table 2. Answers to the fifth question:

"Do you consider that a person's ID should

state whether he/she is an organ donor?"

\begin{tabular}{|cccc|}
\hline & $\begin{array}{c}\text { Secondary } \\
\text { school } \\
\text { students }\end{array}$ & $\begin{array}{c}\text { College } \\
\text { students }\end{array}$ & Total \\
\hline yes & 11 & 19 & 30 \\
\hline no & 13 & 10 & 23 \\
\hline $\begin{array}{c}\text { I do not } \\
\text { know }\end{array}$ & 4 & 1 & 5 \\
\hline Total & 28 & 30 & 58 \\
\hline
\end{tabular}

Most participants, $\mathrm{N}=29$, of whom 14 college students and 15 secondary school students, believe that there is no need for financial compensation to the family donating an organ of a deceased person. On the other hand, 11 participants, 5 college students, and 6 secondary school students believe that the family of the deceased person should be financially compensated. The remaining 18 participants (11 college students and 7 secondary school students) did not express their opinion on this issue. The $\chi^{2}$ test showed that the difference between the responses provided by college students and secondary school students is not statistically significant $\left(\chi^{2}=0.946\right.$, $p=0.623$ ).

When the participants were asked about their attitudes about organ donation, almost all stated that they believe it to be a humane act $(90 \%$ of college students and $86 \%$ of secondary school students).

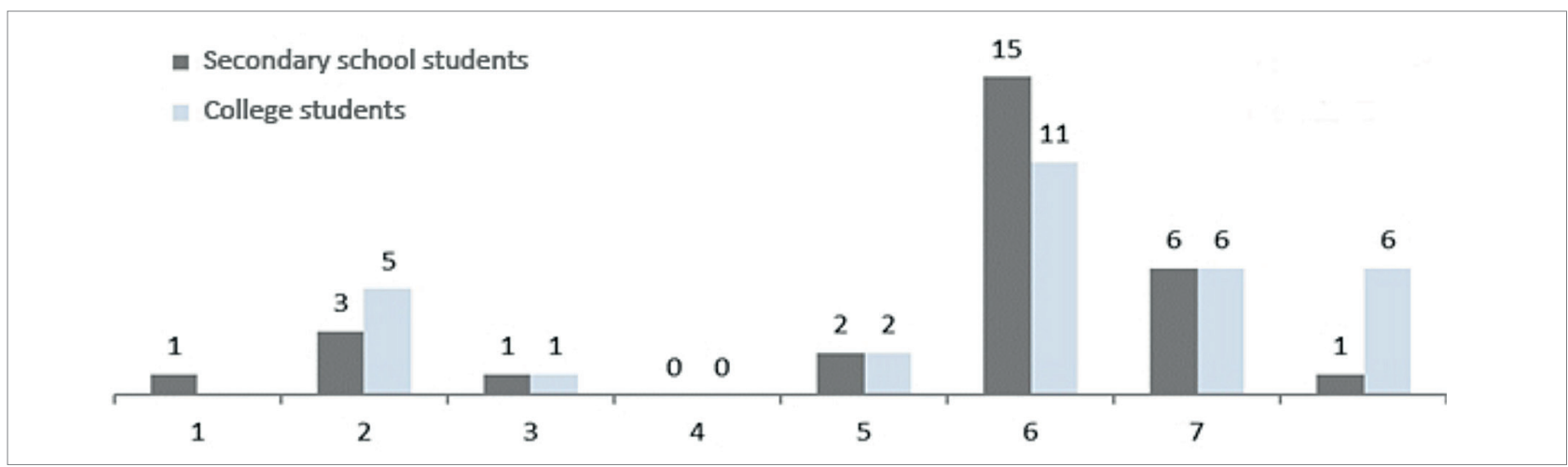

Graph 3. Frequencies for the responses to the item "Choose the reasons why you would not personally want to be an organ donor"

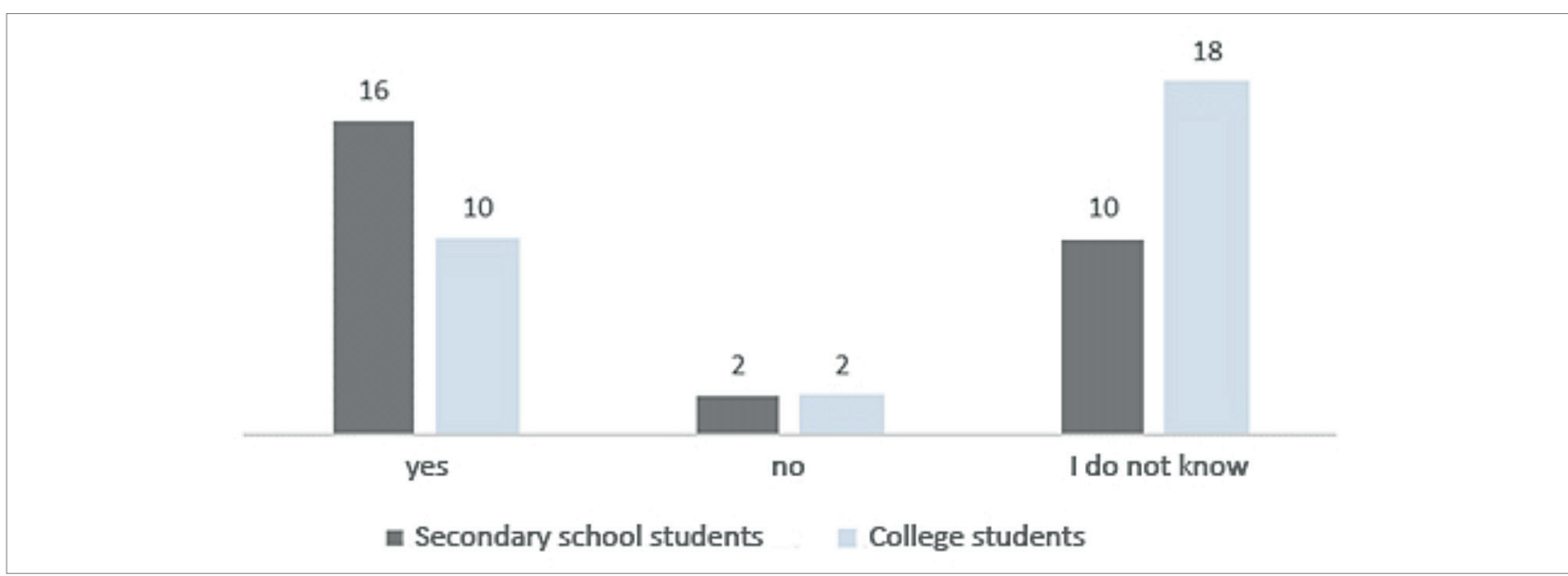

Graph 4. Frequencies for the responses to the item "Would you donate your immediate family members' organs after their death?" 


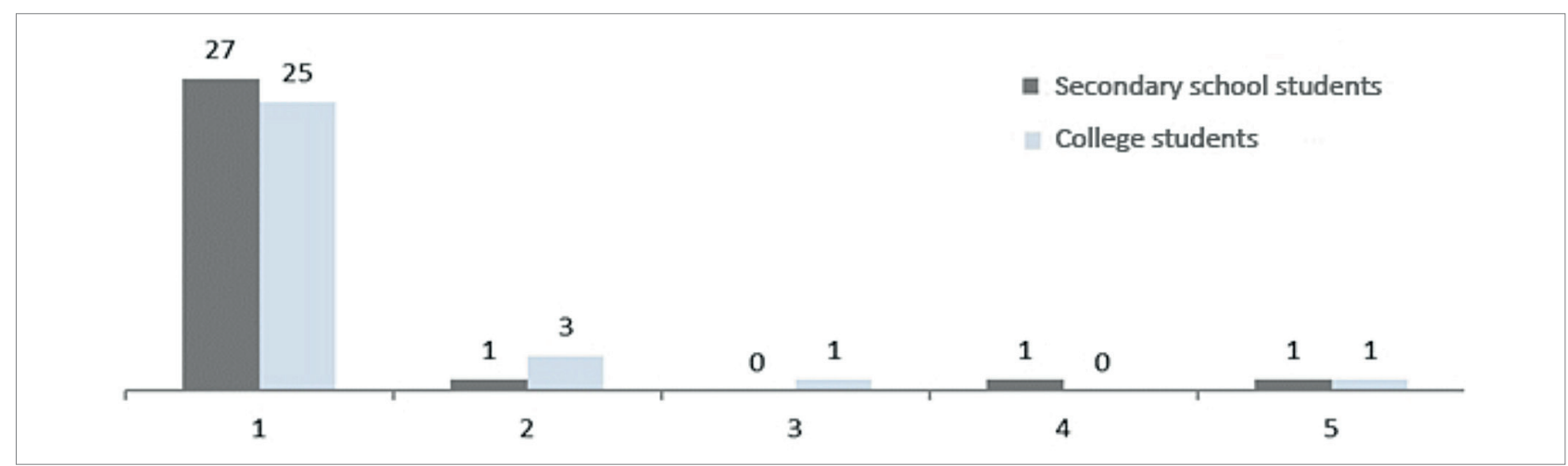

Graph 5. Absolute frequencies for the response to the seventh question: "What is your attitude towards organ donation?"

( 1 - I think it is a humane act, 2 - I think that most organs end up in the "black market", 3 - I would never allow someone to take my organs, or those of my family and those close to me - 4 - I have no opinion about it, 5 - Other)

As many as 54 college and secondary school students believe that different forms of education, brochures, posters and similar aids may have an impact on raising awareness among the population about the importance of organ donation. In addition, the same number of participants believe that the media could also have an important role in raising awareness about the issue among the population.

The difference between the answers to the question whether the participants support the Croatian regulation which states that organs of any adult person who had not, during their lifetime, expressed in writing his/her opposition to being an organ donor can be retrieved without the consent of the family, was not statistically significant according to their level of education $\left(\chi^{2}=0.662 ; p=0.718\right)$.

Participants' answers to the questions pertaining to the organ transplantation process including them or their family members as recipients were largely positive, i.e. $88 \%$ of the participants confirmed they would agree to organ transplantations in both cases.

The last question was related to whether it is necessary to have the information about the donor when receiving an organ during the transplantation process, and the $\chi^{2}$ test showed no statistically significant difference in the opinions expressed by secondary school and college students $\left(\chi^{2}=5.729, p=0.057\right)$.

\section{Discussion}

The aim of the research was to investigate whether the opinions about organ donation expressed by the final year secondary health care students differed from those of the final year students of the undergraduate Nursing study programme. Fisher's test showed no difference in their opinions, that is, both groups ( $>70 \%$ of participants) reported willingness to donate their organs after death. If the results of the present survey are compared to those of a study (11) conducted in 2016 among the employees of the Croatian Army forces in Karlovac, a similarity in attitudes is noticeable. The results showed that $69 \%$ of the members of the armed forces reported willingness to donate their organs, which is $3 \%$ less (in total) in comparison to the results of the present research.

Given the large percentage of participants willing to donate their organs, it was to be expected that most would also agree to donate organs of their family members after their death, but only ten college students responded positively while 18 were indecisive. The results were somewhat different among secondary health care students, as more than $50 \%$ reported willingness to donate organs of their family members, while 10 were indecisive. At the same time, if transplantation could save their or their family members' lives, over $88 \%$ of the participants reported they would agree to transplantation. The $\chi^{2}$ test was applied to confirm if there is a statistically significant difference in the participants' opinions 
about the importance of knowing who the organ donor is. Namely, 11 college students considered it important to know who the donor is while 8 considered it to be irrelevant (others were indecisive). In the case of secondary health care students, the situation is reversed, i.e. eight students considered it important to know who the donor is, while 15 of them considered it to be irrelevant (others were indecisive). The results of the test are surprising since, at the significance level of 0.05 , it may be concluded that there is no statistically significant difference in the participants' responses. It is interesting that almost $50 \%$ of secondary health care students believed that a person's ID card should not contain the information that he/she is an organ donor, while the college students are of different opinion. As many as 19 of them thought this information should be stated. It was expected that there is a statistically significant difference between their opinions, but Fisher's test again showed no difference at the significance level of 0.05 . Both groups of participants stated as the main reason why they would donate organs the fact that it might save someone's life (the most frequent response), and the second reason mentioned was humanity, nobility and solidarity. Considering that most of the participants would donate organs because they consider this to be an act of humanity, it is not surprising that most of them opposed provision of financial compensation to the families who donate the organs of their deceased family members. Given the positive attitudes about donating organs expressed by both groups of participants, it is surprising that 36 of them selected one of the reasons against donating while 23 responses confirmed they wanted to be donors (it was expected that this answer would be selected by a majority). This prompts the question of how much people actually know about the procedure and organizations involved in organ donation. The participants believe that various forms of education, brochures, posters and the like could contribute to the understanding of the importance of organ donation among the general population (as many as 54 out of 58 participants were of this opinion) and the same number of participants believed that the media could significantly influence the population's awareness about organ donation.

The Republic of Croatia is at the top of the European Union with regard to organ retrieval (10), and this is partly because of the way in which the law has been defined. Croatian regulation allows organ retrieval from an adult who had not, during his/her lifetime, declared in writing an opposition to being an organ donor, without the consent of his/her family. Another reason is equally valuable, as it indicates an increase in the number of donors due to a successful organizational model in the Republic of Croatia, primarily the network of transplantation coordinators, valuable work of devoted and enthusiastic health care workers, compliance with bioethical principles and public solidarity and awareness of the benefits of organ transplantation. Nevertheless, it would not have been possible without altruism and selfless help of families who, in the moments of their immense personal tragedy, agree to donate the organs of their loved ones. Despite the above-mentioned law, family decisions are always respected, that is, if the family does not give their consent, organs may not be retrieved. In the present survey, as many as $59 \%$ of the participants expressed their disagreement with the law while 19\% agreed with it. The need for organs has been increasing every year and transplantation can provide patients with a better quality of life. All available tools should be used to ultimately motivate society members to join the donor network and thus increase the percentage of those willing to donate their organs after death.

\section{Conclusion}

Based on the conducted research and the obtained results it can be concluded that:

- the level of education does not affect a person's decision to donate organs,

- the participants' main motivation for deciding to donate organs is the possibility to rescue someone's life,

- organ donation is an act of humanity,

- several participants in the survey expressed negative opinions about organ donation. It is therefore recommended that workshops focusing on the importance of donating organs be organized in secondary health care schools with the objective to raise awareness about the importance of organ donation among health care workers. 


\section{References}

1. Padovan I. Medicinski leksikon. Zagreb: Leksikografski zavod Miroslava Krleže; 1992. Croatian.

2. Tomašević L, Pelčić G. Etičko-kršćanski stavovi o transplantaciji organa. Služba Božja. 2008;48(3):229260. Croatian.

3. Matić V, Kalauz S, Jonjić D. Zdravstvena njega donora organa. Plavi fokus. 2016;2:18-21. Croatian.

4. Hrvatska donorska mreža. Available from: http://www. hdm.hr/. Accessed: 18.09.2018. Croatian.

5. Ministarstvo zdravstva. Zakon o presađivanju ljudskih organa u svrhu liječenja. Narodne Novine; 177/04. i 45/09. Croatian.

6. Topić J, Nesek Adam V, Zirdum D. Uloga anesteziološke sestre/tehničara u postupku eksplantacije organa. Sestrinski glasnik. 2017;22:200-3. Croatian.

7. Fučkar G. Proces zdravstvene njege. Zagreb: Hrvatska udruga za sestrinsku edukaciju; 1996. Croatian.

8. Bušić M, urednica. Vodič za kvalitetu i sigurnost u transplantaciji organa, tkiva i stanica. 1 izdanje. Zagreb: Ministarstvo zdravstva i socijalne skrbi Republike $\mathrm{Hr}$ vatske; 2004. Croatian.

9. Povrzanović I. Hrvatska donorska mreža i njene aktivnosti. Glasnik pulske bolnice. 2007;4 Suppl 1:119122. Croatian.

10. Živčić-Ćosić S, Bušić M, Župan Ž, Pelčić G, Anušić Juričić M, Jurčić Ž, et al. Development of the Croatian model of organ donation and transplantation. Croat Med J. 2013;54(1):65-70.

11. Bajser A. Znanje i stavovi djelatnika hrvatske vojske o transplantaciji [završni rad]. Bjelovar: Visoka tehnička škola u Bjelovaru, 2016. Croatian. 


\section{MIŠLJENJE UČENIKA ZAVRŠNE GODINE SREDNJE MEDICINSKE ŠKOLE I STUDENATA ZAVRŠNE GODINE PREDDIPLOMSKOG STUDIJA SESTRINSTVA O DONIRANJU ORGANA}

\section{Sažetak}

Cilj. Ispitati i usporediti mišljenja učenika završne godine srednje medicinske škole i studenata završne godine preddiplomskog studija sestrinstva o važnosti doniranja organa.

Metode. Provedena je presječna studija na ukupno 60 ispitanika od kojih je 30 učenika srednje medicinske škole i 30 studenata preddiplomskog studija sestrinstva. U prikupljanju podataka primijenjen je upitnik izrađen za potrebe ovog istraživanja koji je sadržavao sljedeće skupine pitanja: u prvoj skupini pitanja o općim podacima ispitanika, a u drugoj skupini pitanja o tematici doniranja organa.

Rezultati. Dobivenim rezultatima utvrđeno je da ne postoji statistički značajna razlika kod donošenja odluke o doniranju organa ovisno o stupnju obrazovanja. Nadalje, rezultati su pokazali da i učenici završne godine srednje medicinske škole i studenti završne godine preddiplomskog studija sestrinstva žele donirati organe te im je glavna motivacija spašavanje nečijeg života, a dodatno većina ispitanika izražava stav da je takvo postupanje human čin.

Zaključak. Stupanj obrazovanja ne utječe na donošenje odluke o doniranju organa. Glavna je motivacija prilikom donošenja odluke o doniranju organa spašavanje nečijeg života. Doniranje organa je human čin. $U$ istraživanju je nekoliko ispitanika izrazilo negativno mišljenje o doniranju organa. Stoga je preporuka da se u srednjim medicinskim školama i ostalim obrazovnim ustanovama za zdravstvene djelatnike organiziraju radionice koje imaju cilj budućim zdravstvenim djelatnicima ukazati na važnost doniranja organa.
Ključne riječi: doniranje organa, transplantacija organa, učenici srednje škole, studenti 